\title{
Genetic diversity of "Pimenta Longa" genotypes (Piper spp., Piperaceae) of the Embrapa Acre germplasm collection
}

\author{
Lúcia Helena de Oliveira Wadt ${ }^{1}$, Christiane Ehringhaus ${ }^{2}$ and Paulo Yoshio Kageyama ${ }^{3}$ \\ ${ }^{1}$ Embrapa/CPAF-Acre, Rio Branco, AC, Brazil. \\ ${ }^{2}$ Yale School of Forestry and Environmental Studies, New Haven, USA and Universidade Federal do Acre, \\ Parque Zoobotânico, Rio Branco, AC, Brazil. \\ ${ }^{3}$ Universidade de São Paulo, Escola Superior de Agricultura Luiz de Queiróz, Departamento de Ciências \\ Florestais, Piracicaba, SP, Brasil.
}

\begin{abstract}
The commonly known Pimenta longa is a commercially valuable natural resource found wild in Acre, Brazil. Specifically, three Piperaceae species with contested taxonomic status were studied, Piper hispidinervum, Piper aduncum, and Piper hispidum, to assesses the inter- and intra-specific genetic relationship of 49 Piper genotypes kept in the Pimenta longa germplasm collection at Embrapa Acre, using sixty six Random Amplified Polymorphic DNA (RAPD) markers. The DNA polymorphism level detected was high (96.97\%), but the marker frequencies for each species showed polymorphism levels of $79.4 \%$ for Piper hispidinervum and $5.3 \%$ for $P$. aduncum. The genetic similarity clustering analysis resulted in three distinct groups corresponding to Piper hispidinervum, Piper aduncum, and Piper hispidum. Four and nine characteristic RAPD markers were identified for $P$. hispidinervum and $P$. aduncum, respectively, supporting the existence of two separate species. However, six genotypes collected in Tarauacá county formed a distinct subgroup within the $P$. hispidinervum group and may be considered as an ecotype of this species or an intermediate between the $P$. hispidinervum and $P$. aduncum groups. More extensive sampling of both $P$. hispidinervum and $P$. aduncum populations throughout the region are needed to further establish their relation and its implication for breeding efforts.
\end{abstract}

Key words: safrole, $P$. hispidinervum, $P$. aduncum, P. hispidum, RAPDs.

Received: May 14, 2003; Accepted: August 4, 2003.

\section{Introduction}

This paper examines the genetic relationships of Pimenta Longa germplasm, a commercially valuable source of safrole oil in the Southwestern Amazonian state of Acre. Specifically, three Piperaceae species with contested taxonomic status were studied, Piper hispidinervum, Piper aduncum, and Piper hispidum, with only $P$. hispidinervum containing significantly higher safrole concentration.

The genus Piper in the Piperaceae family is widely distributed in the understory and secondary vegetation of tropical forests, particularly in Asia and the Neotropics. Piper, which contains more than 1000 species, is characterized by a shrubby to subtree habit, thickened nodes and spicate inflorescences with minute bracteate flowers. People throughout the tropics use Piper for many purposes,

Send correspodence to Lúcia Helena de Oliveira Wadt. Embrapa Acre, Rodovia BR 364 km 14, Caixa Postal 321, 69901-180 Rio Branco, AC, Brazil. E-mail: lucia@cpafac.embrapa.br. such as food, ornamentals, spices, perfumes, oils, fish bait, fish poison, insecticides, hallucinogens, and many medicines (Barrett 1994, Joly 1993, Schultes and Raffauf 1990). A number of compounds have been isolated from Piper, such as terpenes, phenylpropenoids, lignans, other phenolics and a series of alkaloids (Jensen 1993, Hegnauer 1990). Many of these compounds have shown biological activity, particularly as antimicrobials.

A very important group of secondary Piper metabolites are phenylpropenoids, consisting of phenolic structures with terpenoid substitutions that occur as a volatile component in some Piper species. Safrole, dillapiole, myristicine and similar phenylpropanes were identified in several neotropical Piper (Diaz and Gottlieb 1979, Hegnauer 1990). Phenylpropenoids, such as safrole and myrsiticine are widely used in the perfume and flavoring industries. Safrole is in particularly high demand by the cosmetic, insecticide and pesticide industries (Maia et al., 1987).

Despite its commercial and medicinal importance, Piper has received only limited scientific attention. The ge- 
nus has primarily been investigated in Asia, the Indian Piper species have been particularly well analyzed (such as P.nigrum, $P$. longum, $P$. cubeba, $P$. betle and $P$. methysticum). In the new world, only a few Piper species have been the object of in-depth research, including the widely distributed Piper aduncum L., Piper hispidum Sw., Piper auritum H.B.K., Piper peltatum L. (syn. Pothomorphe peltata), Piper umbellatum L. (syn. Pothomorphe umbellata), and Piper amalago L. Little information on the phytochemistry and biological activity of neotropical Piper exists. Even less is known about the genetic diversity of neotropical Piper species.

In the Southwestern Amazonian state of Acre, Brazil, the genus Piper is particularly diverse with over 76 species (http://www.nybg.org/bsci/acre/piperaceae.html, Ehringhaus, 1997). Particular attention has been drawn to a Piper species popularly named "Pimenta longa", that occurs in many cultivated and fallow areas, and is considered a pioneer species in areas with anthropogenic as well as natural disturbance (Almeida, 1999). This species was identified in the 1970 s by researchers at the National Institute for Research in the Amazon (INPA) as a producer of a safrolerich essential oil.

Until the early 1990's, the industry was supplied almost exclusively with safrole obtained from the essential oil extracted from the wood of sassafras (Ocotea pretiosa), a tree native to Southern Brazil. The felling of sassafras, however, was banned by IBAMA (the Brazilian Environmental Protection Agency) in 1991 because of the risk of extinction (Silva, 1993), causing an impact on the world safrole market. Since then, the only world producers have been China and Vietnam, which are not meeting the market demand. As the extraction process in these countries is also destructive, the industry is concerned about the long-term safrole availability (Pimentel et al. 1998). In the case of the pimenta longa, however, the process is non-destructive, as safrole is extracted from its leaves and thin twigs and the plant can re-sprout due to its good vegetative propagation potential (Silva, 1993). In addition, pimenta longa produces very high yields of safrole oil, which is superior in concentration than those found in other sources of safrole.

Because of the commercial potential of the Pimenta longa, Embrapa Acre and the Emílio Goeldi Museum in Belém/PA started bioprospecting studies on this plant in 1992. In 1994, Embrapa Acre began a research project to collect genetic material to establish a germplasm bank. Three species from Acre were identified as a result of this work, showing different safrole concentrations in their oil fraction: $P$. hispidinervum, with a safrole content ranging from $87 \%$ to $97 \%$, P . aduncum, from $0.10 \%$ to $3.24 \%$ and P. hispidum with less than $1 \%$ (Silva and Oliveira, 2000). In this survey, $P$. hispidinervum was found only in the Acre river valley, while $P$. aduncum was identified throughout the state, and was more abundant in the Juruá and Purus river valleys (Pimentel et al. 1998). P. hispidum is found throughout the state, mainly in shaded environments (Figure 1)

However, some questions remain unanswered regarding the identity and genetic diversity of safroleproducting Piper species in the region, especially concerning the promising Piper hispidinervum. In particular, Piper hispidinervum and Piper aduncum are difficult to distinguish morphologically, although they have very distinct levels of safrole concentration. While Yuncker (1972) describes $P$. hispidinervum as a distinct species, Callejas (personal communication) and Silva (1993) argue that Piper hispidinervum represents a group within Piper aduncum and does not stand as a separate species. Piper hispidum is a common species throughout disturbed and forest sites in tropical South America. Piper aduncum is a widely distributed species that occurs in areas of natural and anthropogenic disturbance throughout tropical South and Central America, and the Caribbean and has been introduced to other tropical areas in the world. However, the hypothesized Piper hispidinervum has a very limited distribution in the South Western Amazon, particularly in the state of Acre. Hence, the question exists whether Piper hispidinervum is a distinct species with high safrole concentration and limited geographic distribution or a distinct variety within a large Piper aduncum.

Therefore, to elucidate the relationships between these groups and to assess the genetic variability of safrole producing Piper in the region, the genetic relationships need to be examined among these plant groups. By complementing the horticultural and phytochemical work with an analysis of the genetic relationships on these Piper species, this paper seeks to contribute to this discussion.

The genetic characterization of the germplasm of any species is fundamental because it contributes to the effective conservation by revealing the magnitude of the genetic relationship among accessions in a collection and by allow-

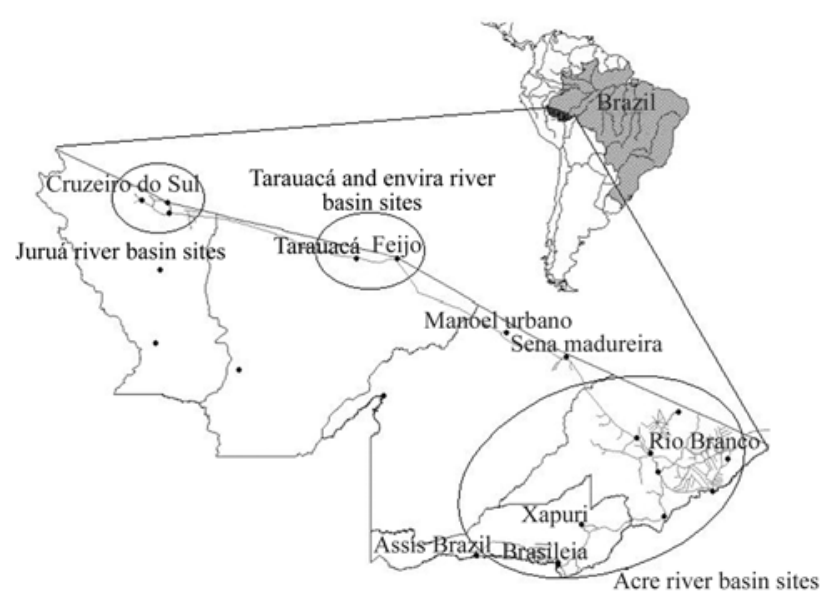

Figure 1 - Map of the state of Acre, Southwestern Amazonia, Brazil, showing the sites where the Pimenta longa genotypes were collected (Map data source: Zoneamento Econômico-Ecológico, Acre State Government, 1999). 
ing estimates of the sample genetic diversity (Bhat et al. 1999). Molecular markers have been widely used for the genetic characterization of germplasm of several cultivated species (Mekuria et al. 1999; Rodriguez et al. 1999; Bhat et al. 1999; Margale et al. 1995; Virk et al. 1995). They have also been used as an important tool to obtain information which optimizes germplasm use in breeding programs.

RAPD markers have been widely used in genetic diversity studies due to their great resolution power compared to morphological markers, the large number of DNA bands (markers) that can be obtained in relation to isoenzymes and because of their simplicity and practicality compared to other DNA markers (Bhat et al. 1999). RAPD markers have been effectively used for cultivar or varietal identification in some vegetables such as Capsicum annuum (Ilbi, 2003), tomato (Noli et al., 1999); cabbage and cauliflower (Hu and Quiros, 1991).This study used RAPD markers to assess the genetic diversity and the inter-specific relationships of the genetic material in the Pimenta longa germplasm collection at Embrapa Acre.

\section{Material and Methods}

\section{Plant material}

After identification and mapping of the Pimenta longa species, cuttings were collected by Embrapa from individuals in various locations throughout the state of Acre (Figure 1) to start a germplasm bank and to identify genetic materials with safrole content greater than $90 \%$ in the oil fraction. Preference was given to $P$. hispidinervum, but some $P$. hispidum and $P$. aduncum individuals were also collected. The number of individuals (clones) of each genotype in the collection ranged from one to nineteen. Twenty-one genotypes (accessions) represented by 111 individuals were obtained in November 1995. In July and November 1996, 28 genotypes were added to the collection resulting in a total of 49 genotypes.

Herbarium specimens of the germplasm bank were sent to and deposited in the Jardim Botânico in Rio de Janeiro/RJ for identification and three species were identified by Elsie Franklin Guimarães ( $P$. hispidinervum, $P$. aduncum and $P$. hispidum). A fourth species was tentatively identified as Piper affinis hispidinervum. The morphological differentiation between $P$. hispidinervum and $P$. aduncum concentrates on the leaf characteristics: a) $P$. hispidinervum has pubescent twigs and oblong-lanceolate or oblong-elliptic leaves, slightly rough on the ventral surface; b) $P$. aduncum has elliptic or lanceolate leaves with a round or cordate base, rough on the ventral surface and pubescent on the dorsal and ventral sides (Yuncker, 1972). In addition, most of the genetic material, except genotypes BAG 047, BAG 053 and BAG 080, were characterized for oil yield and safrole content in the oil (unpublished data from the Food Technology Laboratory at Embrapa-Acre).
All the genotypes in the Pimenta longa germplasm collection established in the Embrapa Acre experimental field in 1995 were assessed in this study. Collection sites of the different genotypes are illustrated in Figure 1. A total of 49 distinct genotypes are maintained, 16 of which have not yet been classified (unpublished data). Table 1 lists the material used in this study with the botanical identification, origin, as well as oil and safrole yield.

\section{DNA extraction and RAPD reaction}

Totally expanded young leaves were collected from each genotype and dried on silica gel. The dry leaves were taken to the Laboratório de Reprodução e Genética de Espécies Arbóreas - LARGEA (Tree Reproduction and Genetics Laboratory), of the Department of Forest Science at ESALQ/USP in Piracicaba-SP, where the DNA was extracted and the RAPD markers analyzed.

The DNA was extracted according to Ferreira and Grattapaglia (1996) with a modified extraction buffer (100 mM Tris-HCl, pH 8.0, 20 mM EDTA, $1.4 \mathrm{M} \mathrm{NaCl}$, $2 \%$ CTAB, 1\% Sarkozyl and 0.1\% 2-Mercaptoethanol). The DNA concentration was estimated by comparing the samples with known quantities of $\lambda$ phage DNA stained with ethidium bromide (400 ng, $200 \mathrm{ng}$ e $100 \mathrm{ng}$ ) in 1\% agarose gel after electrophoresis in 0.5X TBE buffer ( $50 \mathrm{mM}$ Tris; $45 \mathrm{mM}$ boric acid; $0.5 \mathrm{mM}$ EDTA). The DNA samples were then diluted to $4 \mathrm{ng} / \mu \mathrm{L}$.

The protocol used to amplify the DNA sequences by PCR was based on Williams et al. (1990). Four different genotypes were tested with Operon Technologies primer sets A, B and C to select those primers, which amplified the greatest number of polymorphic bands with good reading quality.

Amplification reactions were done in a Techne thermocycler, Genius model. Each reaction $(13 \mu \mathrm{L})$ contained 1X PCR buffer (10mM Tris- $\mathrm{HCl}, 50 \mathrm{mM} \mathrm{KCl}$ and $1.5 \mathrm{mM} \mathrm{MgCl} 2)$, dNTPs (200 $\mu$ M each), BSA $(10 \mathrm{mg} / \mathrm{mL})$, primer $(0.2 \mu \mathrm{M}), 1$ unit of Taq DNA polymerase and $10 \mathrm{ng}$ of DNA. The DNA was amplified using a step-wise/threestep program with:

1) One minute at $95^{\circ} \mathrm{C}$, then

2) 40 cycles of:

-1 min at $92^{\circ} \mathrm{C}$ for DNA denaturation, followed by

$-1 \mathrm{~min}$ at $35^{\circ} \mathrm{C}$ for primer annealing,

- and 2 min at $72{ }^{\circ} \mathrm{C}$ to extend the primer, and finally

3) After the $40^{\text {th }}$ cycle a final seven-minute step at $72{ }^{\circ} \mathrm{C}$ to extend the amplified products.

After amplification, the DNA fragments were separated by electrophoresis for about four hours under constant voltage $(120 \mathrm{~V})$ in $1.5 \%$ agarose gels, submersed in $0.5 \mathrm{X}$ TBE buffer. The gels were stained with ethidium bromide and observed under ultraviolet light. Each gel was photodocumented using a Kodak (KD 1D 2.0) electronic image capturing system. 
Table 1 - Identification of the assessed materials, showing genotype code, species, origin (city in the state of Acre), oil yield and safrole content in the oil fraction.

\begin{tabular}{|c|c|c|c|c|c|}
\hline Gen. cod. & Genotype & Species & Origin (city) & Oil(\%) & Safrole (\%) \\
\hline 1 & В 014 & not identified & Plác. de Castro & 3.59 & 91.87 \\
\hline 2 & В 015 & P. hispidinervum & Plác. de Castro & 2.88 & 95.09 \\
\hline 3 & В 016 & P. hispidinervum & Plác. de Castro & 3.05 & 96.30 \\
\hline 4 & В 017 & P. hispidinervum & Plác. de Castro & 3.15 & 95.04 \\
\hline 5 & В 018 & P. hispidinervum & Plác. de Castro & 3.02 & 95.16 \\
\hline 6 & В 019 & P. hispidinervum & Plác. de Castro & 2.92 & 95.79 \\
\hline 7 & В 034 & P. hispidinervum & Acrelandia & 2.04 & 91.46 \\
\hline 8 & В 040 & P. hispidinervum & Sen. Guiomard & 2.54 & 90.56 \\
\hline 9 & В 042 & P. hispidinervum & Sen. Guiomard & 2.07 & 93.87 \\
\hline 10 & В 043 & P. hispidinervum & Sen. Guiomard & 2.37 & 94.02 \\
\hline 11 & В 044 & P. hispidinervum & Sen. Guiomard & 2.46 & 96.47 \\
\hline 12 & В 045 & P. hispidinervum & Sen. Guiomard & 2.07 & 92.58 \\
\hline 13 & В 046 & P. hispidinervum & Sen. Guiomard & 2.07 & 90.39 \\
\hline 14 & В 047 & not identified & Porto Acre & - & - \\
\hline 15 & В 050 & P. hispidinervum & Porto Acre & 2.61 & 94.31 \\
\hline 16 & В 051 & P. hispidinervum & Porto Acre & 2.00 & 93.59 \\
\hline 17 & В 052 & P. hispidinervum & Bujari & 3.54 & 92.87 \\
\hline 18 & В 053 & not identified & Bujari & 3.57 & - \\
\hline 19 & В 067 & P. hispidinervum & Brasiléia & 2.81 & 91.18 \\
\hline 20 & В 075 & not identified & Brasiléia & 5.27 & 94.63 \\
\hline 21 & В 080 & not identified & Assis Brasil & 5.05 & - \\
\hline 22 & В 084 & not identified & Sen. Guiomard & 4.58 & 94.01 \\
\hline 23 & В 086 & not identified & Sen. Guiomard & 4.00 & 95.06 \\
\hline 24 & В 090 & P. hispidinervum & Assis Brasil & 3.37 & 96.02 \\
\hline 25 & В 100 & P. hispidinervum & Bujari & 3.41 & 96.50 \\
\hline 26 & В 103 & P. hispidinervum & Bujari & 3.48 & 96.97 \\
\hline 27 & В 109 & P. aduncum & Cruzeiro do Sul & 3.67 & Trace \\
\hline 28 & В 110 & P. aduncum & Cruzeiro do Sul & 3.59 & 0.17 \\
\hline 29 & В 111 & P. aduncum & Cruzeiro do Sul & 3.55 & 0.10 \\
\hline 30 & В 112 & P. aduncum & Cruzeiro do Sul & 2.82 & 3.24 \\
\hline 31 & В 113 & P. aduncum & Cruzeiro do Sul & 5.68 & 1.03 \\
\hline 32 & В 114 & P. aduncum & Cruzeiro do Sul & 3.95 & Trace \\
\hline 33 & В 115 & P. aduncum & Mâncio Lima & 4.39 & Trace \\
\hline 34 & В 116 & P. aduncum & Mâncio Lima & 4.85 & Trace \\
\hline 35 & В 117 & P. aduncum & Rodrigo Alves & 4.83 & Trace \\
\hline 36 & В 118 & P. aduncum & Rodrigo Alves & 3.57 & Trace \\
\hline 37 & В 119 & P. aduncum & Rodrigo Alves & 3.68 & Trace \\
\hline 38 & В 120 & P. aduncum & Rodrigo Alves & 3.58 & 0.15 \\
\hline 39 & В 121 & P. aduncum & Rodrigo Alves & 4.32 & 0.08 \\
\hline 40 & В 127 & P. hispidum & Feijó & 1.33 & 0.14 \\
\hline 41 & В 137 & not identified & Tarauacá & 4.49 & 15.33 \\
\hline 42 & В 138 & not identified & Tarauacá & 3.99 & 40.87 \\
\hline 43 & В 139 & not identified & Tarauacá & 4.04 & 18.43 \\
\hline 44 & В 141 & not identified & Tarauacá & 3.47 & 4.64 \\
\hline 45 & В 142 & not identified & Tarauacá & 4.94 & 28.14 \\
\hline 46 & В 144 & not identified & Tarauacá & 3.87 & 24.65 \\
\hline 47 & В 145 & not identified & Bujari & 4.37 & 92.44 \\
\hline 48 & В 147 & not identified & Xapuri & 5.37 & 87.26 \\
\hline 49 & B 148 & not identified & Xapuri & 1.66 & 0 \\
\hline
\end{tabular}

${ }^{1}$ Free humid yield. 


\section{Data reading and analysis}

Each amplification product (band) was considered to be a RAPD marker. Consistent markers were read for all the individuals. Number one was attributed to band presence and zero to absence. A $1 \mathrm{~kb}$ fragment size marker was used as a reference to allow comparison among the different gels (Gibco 1kb ladder).

The binary data set was used to calculate the pairwise Jaccard similarity index and to assemble the corresponding similarity matrix. The matrix obtained was used to generate a dendrogram using the UPGMA method (Unweigthed Pair Group Method Arithmetical Means). The distances in the dendrogram were compared with the genetic distances between genotype pairs to calculate the cophenetic correlation. All the analyses were performed with the aid of the 1.70 version of the NTSYS-pc computer program. The stability of each knot in the dendrogram was tested by bootstrap analysis, using the BOOD software, version 3.0 (Coelho, 2001).

The 49 genotypes were classified according to the botanically identified species and the results of the Jaccard group similarity index. Genotypes with taxonomic identification based on RAPD agreeing with the botanical classification were used to detect exclusive markers for $P$. hispidinervum and $P$. aduncum. P. hispidum was not included in this analysis because only one genotype of the species is included in the collection. The criterion to define an exclusive marker for a given species was its occurrence in at least $90 \%$ of the individuals of that taxonomic species and complete absence in the other.

Finally, the presence of exclusive markers was investigated in the genotypes that were not conclusively identified as a particular taxon but that grouped within a given species and were classified as belonging to it. In the cases where a group could not be established, species characterization was not confirmed although the presence or absence of exclusive markers suggested a tendency. Further studies with an increased number of markers and also using other methodologies are necessary to confirm these results.

\section{Results}

\section{Multiband polymorphism}

Sixteen out of the 60 tested primers were selected and used to amplify the DNA of the 49 Pimenta longa genotypes but only six (OP-A5, OP-A8, OP-A12, OP-B8, OP-B11 and OP-B12) resulted in suitable bands for reading and analysis. Figure 2 shows the DNA fragments obtained with primer OP-B12. The DNA analysis resulted in 79 bands, of which 66 $(83.4 \%)$ were analyzed. Overall, each primer amplified an average of 11 bands (between 5 and 19), but not all were sufficiently clear for analysis. Across all samples 64 RAPDs loci/bands $(96.97 \%)$ were polymorphic (Table 2).

Examining each species, there was a great difference between $P$. hispidinervum and P. aduncum in relation to the polymorphism levels and the number of bands amplified per primer. A total of $79.4 \%$ of the RAPD loci were polymorphic in $P$. hispidinervum whereas only $5.3 \%$ of the RAPD loci were polymorphic in P. aduncum revealing the very distinct genetic characteristics of these two species. Each primer amplified on average 5.67 bands in $P$. hispidinervum, while the mean for $P$. aduncum was 3.17. P. hispidum could not be assessed for polymorphism because there was only one genotype in the collection.

Table 2 - Number of RAPD markers amplified per primer and number of monomorphic and polymorphic markers.

\begin{tabular}{lcccc}
\hline \multirow{2}{*}{ Primer } & & \multicolumn{3}{c}{ Markers } \\
\cline { 3 - 4 } & Amplified & Analysed & Monomorphic & Polymorphic \\
\hline OP-A05 & 14 & 8 & 1 & 7 \\
OP-A08 & 9 & 7 & 0 & 7 \\
OP-A12 & 5 & 4 & 1 & 3 \\
OP-B08 & 15 & 15 & 0 & 15 \\
OP-B11 & 19 & 19 & 0 & 19 \\
OP-B12 & 17 & 13 & 0 & 13 \\
\hline Total & 79 & 66 & 2 & 64 \\
\hline
\end{tabular}

Figure 2 - Amplification products obtained with primer OP-B12. Numbers 1 to 49 indicate the Pimenta longa genotypes analyzed, as Table 1 . M= size markers (1 kb ladder from Gibco). 


\section{Genetic relationship among genotypes in the} germplasm collection

The Jaccard similarity coefficient calculations of the UPGMA dendrogram resulted in three large groups among the examined genotypes. These groups can be considered as corresponding to the three putative species under study, and were thus designated hispidinervum, aduncum and hispidum (Figure 3). The cophenetic correlation that evaluates the relationship among the genetic distances and the distances generated by the dendrogram, was high enough $(r=0.97)$ to indicate that the groups formed by the dendrogram correspond to the genetic data.

Another way to test the cohesion of these groups is by using the consistency test of the knots that form them. In this analysis, the knots responsible for the groups denominated hispidinervum, aduncum and hispidum had a consistency of $98.5 \%, 100 \%$ and $99.8 \%$, respectively. Therefore, these results show a strong consistency for the formation of these groups.

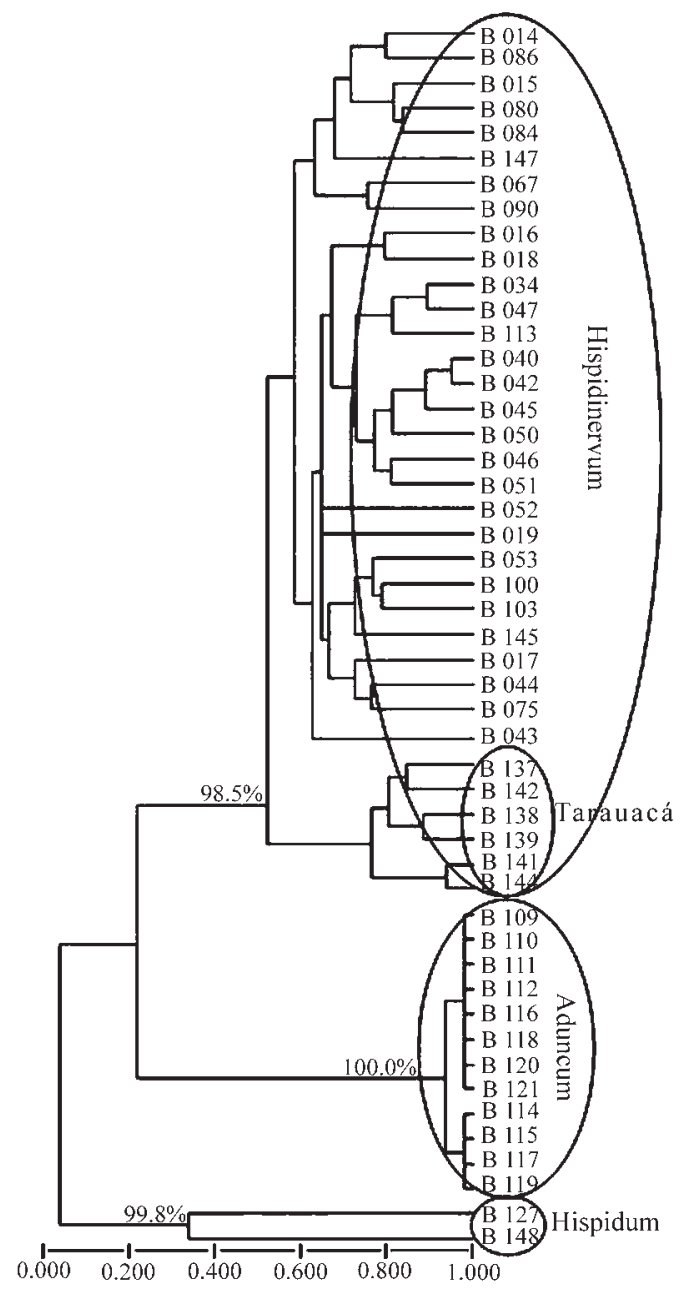

Figure 3 - UPGMA Dendrogram of 49 Pimenta Longa genotypes based on Jaccard similarity, showing three main groups and Tarauacá's subgroup. Number on branches represents the consistency of the knot generated with 1000 bootstraps.
Within the sampled germplasm, sixteen genotypes could not be conclusively botanically identified (Table 1). Out of these, nine grouped with the $P$. hispidinervum genotypes and six formed a subgroup within the hispidinervum group in the dendrogram (Table 3 ). The genotypes in this subgroup were all collected in the Tarauacá area and will be henceforth referred to as the Tarauacá subgroup. The remaining genotype (B 148) was different from all the others, although some similarity with the $P$. hispidum genotypes was observed. The B 113 genotype, identified as $P$. aduncum, did not group with the others in this species, but with those of $P$. hispidinervum, suggesting an identification error.

The marker frequency analysis in each species showed several markers which were exclusive to each of these groups and the Tarauacá subgroup, considering the six genotypes from Tarauacá (B137, B142, B138, B139, $\mathrm{B} 141$ and B144) as a distinct group from $P$. hispidinervum and the B148 genotype as belonging to the P. hispidum group (Table 3). Ten markers were exclusive to $P$. hispidinervum, 10 to $P$. aduncum, three to the Tarauacá genotypes, 23 to $P$. hispidum and 10 were common to both $P$. hispidinervum and Tarauacá genotypes. Only two (3.03\%) markers (OP-A5a and OP-A12c) of the 66 analyzed were monomorphic for all genotypes and appeared in all groups.

Four and nine characteristic markers were identified for the $P$. hispidinervum and $P$. aduncum species, respectively, based on these results and considering the minimum frequency criterion of 0.90 . All markers present in $P$. hispidinervum with frequency greater than 0.90 , and absent in the other species, were detected in all genotypes from the Tarauacá group.

\section{Discussion}

The polymorphism analyses showed that, in general, a high genetic variability was present in the Pimenta longa germplasm collection. Within the collection the dendrogram obtained with the Jaccard similarity index resulted in three distinct groups, which can be tentatively regarded as equivalent to the three putative species under study (P. hispidinervum, P. aduncum, and P. hispidum).

Based on the presence of exclusive markers, fifteen of the sixteen genotypes from the germplasm collection without conclusive botanical identification could be classified as $P$. hispidinervum. Nine out of the 15 could be classified as typical Pimenta longa (P. hispidinervum) (BAG 14, BAG 47, BAG 53, BAG 75, BAG 80, BAG 84, BAG 86, BAG 145, and BAG 147) and the six remaining genotypes (BAG 137, BAG 138, BAG 139, BAG 141, BAG 142 and BAG 144) are representatives of the ecotype from the Tarauacá and Envira river valleys. Only one genotype (BAG 148) could not be classified.

In addition, there probably was an identification error. The RAPD analysis of the individual treated as BAG 113 genotype ( $P$. aduncum) indicates that it is $P$. 
Table 3 - RAPD marker frequency for each primer and taxonomic group.

\begin{tabular}{|c|c|c|c|c|}
\hline \multirow[t]{2}{*}{ Locus } & \multicolumn{4}{|c|}{ Marker frequency } \\
\hline & hispidinervum & aduncum & Tarauacá & hispidum \\
\hline $\mathrm{A} 5 \mathrm{a}$ & 1.00 & 1.00 & 1.00 & 1.00 \\
\hline $\mathrm{A} 5 \mathrm{~b}$ & 0.00 & 0.00 & 0.00 & 0.50 \\
\hline $\mathrm{A} 5 \mathrm{c}$ & 0.00 & 0.00 & 0.00 & 1.00 \\
\hline A5d & 0.82 & 0.00 & 0.00 & 0.00 \\
\hline $\mathrm{A} 5 \mathrm{e}$ & 0.61 & 1.00 & 0.67 & 0.00 \\
\hline A5f & 0.39 & 0.00 & 0.50 & 0.00 \\
\hline $\mathrm{A} 5 \mathrm{~g}$ & 0.00 & 1.00 & 0.00 & 0.00 \\
\hline $\mathrm{A} 5 \mathrm{~h}$ & 0.00 & 0.00 & 0.00 & 1.00 \\
\hline A8a & 1.00 & 0.00 & 1.00 & 0.00 \\
\hline $\mathrm{A} 8 \mathrm{~b}$ & 0.00 & 1.00 & 0.00 & 0.00 \\
\hline $\mathrm{A} 8 \mathrm{c}$ & 0.00 & 0.00 & 0.00 & 1.00 \\
\hline $\mathrm{A} 8 \mathrm{~d}$ & 0.82 & 0.00 & 1.00 & 0.00 \\
\hline $\mathrm{A} 8 \mathrm{e}$ & 0.00 & 1.00 & 0.00 & 0.00 \\
\hline A8f & 0.00 & 0.00 & 0.00 & 0.50 \\
\hline $\mathrm{A} 8 \mathrm{~g}$ & 0.00 & 0.00 & 0.00 & 1.00 \\
\hline A12a & 0.68 & 0.00 & 0.00 & 0.00 \\
\hline $\mathrm{A} 12 \mathrm{~b}$ & 0.64 & 1.00 & 1.00 & 0.00 \\
\hline $\mathrm{A} 12 \mathrm{c}$ & 1.00 & 1.00 & 1.00 & 1.00 \\
\hline $\mathrm{A} 12 \mathrm{~d}$ & 0.00 & 0.00 & 0.00 & 0.50 \\
\hline B8a & 0.14 & 0.00 & 0.00 & 0.00 \\
\hline B8b & 0.86 & 0.00 & 0.83 & 0.00 \\
\hline B8c & 1.00 & 1.00 & 1.00 & 0.00 \\
\hline B8d & 0.00 & 1.00 & 0.00 & 0.00 \\
\hline B8e & 0.07 & 0.00 & 0.33 & 0.00 \\
\hline B8f & 0.00 & 0.00 & 0.00 & 0.50 \\
\hline B8g & 0.11 & 0.00 & 1.00 & 0.00 \\
\hline B8h & 0.00 & 0.00 & 0.33 & 0.00 \\
\hline B8i & 0.07 & 0.00 & 0.00 & 0.00 \\
\hline B8j & 0.00 & 0.00 & 0.00 & 0.50 \\
\hline B8k & 0.00 & 0.00 & 0.00 & 1.00 \\
\hline B81 & 0.00 & 0.00 & 0.00 & 0.50 \\
\hline B8m & 0.00 & 1.00 & 0.00 & 0.00 \\
\hline B8n & 0.54 & 1.00 & 0.83 & 0.00 \\
\hline B8o & 0.00 & 1.00 & 0.00 & 0.00 \\
\hline B11a & 0.00 & 0.00 & 0.00 & 0.50 \\
\hline B11b & 0.00 & 0.00 & 0.17 & 0.00 \\
\hline B11c & 0.43 & 0.00 & 0.00 & 0.00 \\
\hline B11d & 0.32 & 0.00 & 0.00 & 0.00 \\
\hline B11e & 0.00 & 0.00 & 0.00 & 0.50 \\
\hline B11f & 0.00 & 0.00 & 0.00 & 0.50 \\
\hline B11g & 0.46 & 0.00 & 0.83 & 0.00 \\
\hline B11h & 0.00 & 0.00 & 0.00 & 1.00 \\
\hline B11i & 0.96 & 0.00 & 1.00 & 0.00 \\
\hline B11j & 0.00 & 0.00 & 0.00 & 1.00 \\
\hline B $11 \mathrm{k}$ & 0.00 & 1.00 & 0.00 & 0.00 \\
\hline B111 & 0.00 & 0.67 & 0.00 & 0.00 \\
\hline $\mathrm{B} 11 \mathrm{~m}$ & 1.00 & 0.00 & 1.00 & 0.00 \\
\hline B11n & 0.39 & 1.00 & 1.00 & 0.00 \\
\hline B11o & 0.64 & 0.00 & 0.00 & 0.00 \\
\hline B11p & 0.57 & 0.00 & 0.00 & 0.00 \\
\hline $\mathrm{B} 11 \mathrm{q}$ & 0.00 & 0.00 & 0.00 & 1.00 \\
\hline $\mathrm{B} 11 \mathrm{r}$ & 0.00 & 0.00 & 0.00 & 1.00 \\
\hline B11s & 0.00 & 1.00 & 0.00 & 0.00 \\
\hline $\mathrm{B} 12 \mathrm{a}$ & 0.21 & 0.00 & 0.00 & 0.00 \\
\hline $\mathrm{B} 12 \mathrm{~b}$ & 1.00 & 1.00 & 1.00 & 0.00 \\
\hline $\mathrm{B} 12 \mathrm{c}$ & 0.00 & 0.00 & 0.00 & 0.50 \\
\hline $\mathrm{B} 12 \mathrm{~d}$ & 0.96 & 0.00 & 0.00 & 0.00 \\
\hline $\mathrm{B} 12 \mathrm{e}$ & 0.00 & 0.00 & 0.00 & 0.50 \\
\hline B12f & 0.00 & 0.00 & 0.00 & 0.50 \\
\hline $\mathrm{B} 12 \mathrm{~g}$ & 0.00 & 0.00 & 0.00 & 0.50 \\
\hline $\mathrm{B} 12 \mathrm{~h}$ & 0.00 & 0.00 & 0.17 & 0.00 \\
\hline B12i & 0.00 & 0.00 & 0.00 & 0.50 \\
\hline B12j & 0.54 & 1.00 & 1.00 & 0.00 \\
\hline $\mathrm{B} 12 \mathrm{k}$ & 0.79 & 0.00 & 0.00 & 0.00 \\
\hline B121 & 0.00 & 1.00 & 0.00 & 0.00 \\
\hline $\mathrm{B} 12 \mathrm{~m}$ & 1.00 & 0.00 & 1.00 & 0.00 \\
\hline
\end{tabular}

hispidinervum and not $P$. aduncum. A botanical assessment made of this individual in the field confirmed that indeed it belongs to the $P$. hispidinervum species, suggesting an exchange of cuttings when the germplasm collection was implanted in the field.

\section{Piper hispidum - distinct from the aduncum-hispidinervum complex}

A comprehensive discussion on the genetic relationship of $P$. hispidum with the other species was precluded by the existence of a single botanically classified genotype of this species in the germplasm analyzed. Although the similarity coefficient between BAG 148 (unidentified) and BAG 127 (P. hispidum) was low (0.36), they were considered for analysis and discussion purposes as belonging to the same taxonomic group due to the similarities of their morphology and the composition of their oil fraction.

The RAPD markers present in this $P$. hispidum genotype (BAG 127) and the unidentified BAG 148 were quite distinct from those observed in the other species (Table 3). Only two of the 25 RAPD markers analyzed for these genotypes (OP-A5a and OP-A12c) were present in the other species. These markers were monomorphic for all three examined groups and probably are present in a number of Piper species of the region as well.

Moreover, morphologically and ecologically, $P$. hispidum is quite distinct from both $P$. aduncum and $P$. hispidinervum. Different from these two species, $P$. hispidum occurs both in secondary vegetation environments as well as shaded forested sites. Although further studies to support this conclusion would be useful, its relevance regarding the breeding efforts of Pimenta Longa germplasm would be probably limited.

\section{Piper aduncum- a monomorphic group}

While overall the Pimenta longa germplasm revealed a high degree of polymorphism, the collected $P$. aduncum germplasm contained a low genetic variability. The group formed by the $P$. aduncum individuals was very homogeneous with a degree of similarity close to 1.00 , indicating that there is essentially no genetic diversity for this species in the germplasm collection. This high degree of monomorphism suggests the possibility of high rates of selfpollination. This is supported by a study of the pollination ecology of Southeastern Brazilian Piperaceae, in which $P$. aduncum had elevated levels of spontaneous selfpollinization (Figueiredo, 1997). There are little genetic differences among individuals from the same population in self pollinating species and most of the genetic variability is found among populations (Jain, 1976; Loveless and Hamrick, 1984; Linhart and Grant, 1996). Also, $P$. aduncum has a tendency to form large stands of plants that reproduce vegetatively. All the genotypes analyzed in this group are from the Juruá valley (Figure 1), and may therefore be part of a same large, relatively homogenous popula- 
tion. Thus, germplasm from other regions should be collected and characterized to ensure greater variability in the $P$. aduncum materials in the germplasm bank at Embrapa Acre.

As $P$. aduncum is a species with pan-tropical distribution (although with neotropical origins) that occurs abundantly in sites with natural and anthropogenic disturbance, it might be useful to include $P$. aduncum samples from other Amazonian and South American sites to assess the degree of variation within a broader area, as well as to more extensively determine the full range of possible safrole concentration within that species.

\section{Piper hispidinervum - a distinct species from $P$. aduncum?}

The $P$. hispidinervum group contained much higher genetic variability, including both germplasm from the Acre river valley and the Tarauacá/Envira areas. Concurrently, isoenzymatic data indicate that this might be a preferentially outcrossing species (our unpublished data).

There is an ongoing discussion among Pimenta longa researchers regarding the status of $P$. hispidinervum as a species. Many researchers champion Yuncker's (1972) classification that determined $P$. hispidinervum as a distinct species. However, Callejas (quoted by Silva, 1993) today's taxonomic specialist on neotropical Piper species, considers the hispidinervum germplasm as a variety of $P$. aduncum.

In this study, the RAPD markers suggest that $P$. hispidinervum and $P$. aduncum are distinct groups, as both the degree of polymorphism and the number of amplified markers per primer were quite different for the two groups, although $P$. aduncum is represented by collections from one region only. Also, the number of markers which were common to $P$. hispidinervum and $P$. aduncum was relatively low, approximately $13.6 \%$. In addition, chemical analysis of the components found in the essential oil is able to distinguish these two putative species. The safrole content in the oil fraction of $P$. hispidinervum is usually greater than $80 \%$ whereas in P. aduncum it is almost absent. Dillapiol, a phenylpropenoid similar to safrole, predominates in the oil extracted from $P$. aduncum. Therefore, the results presented in this study give support to the hypothesis that $P$. hispidinervum and $P$. aduncum are indeed two distinct groups, and possibly even two distinct species.

However, this debate might be complicated by the variation found within the hispidinervum group. The subgroup formed by the six genotypes from Tarauacá county (identified at Jardim Botânico in Rio de Janeiro as $P$. affinis hispidinervum) clustered within the $P$. hispidinervum group (Figure 3) that originates in the Acre river valley (see Figure 1). Besides this difference in the places of occurrence of the genotypes within the hispidinervum group and Tarauacá subgroup, the chemical components of the oil fraction were different. The average safrole content of the
Tarauacá subgroup was $22.01 \%$, which is significantly lower than the genotypes in the remaining hispidinervum group, which contained $93.7 \%$ on average. A chemical analysis carried out with the oil extracted from the genotypes from Tarauacá showed a predominance of a third component, salicin, which is chemically quite distinct from phenylpropenoids such as safrol and dillapiol, which are typical for many Piper species.

While the chemical data indicates pronounced differences, the analysis of the RAPD marker frequencies showed that $63.3 \%$ of the markers, which appeared in $P$. hispidinervum also appeared in the genotypes from Tarauacá. Furthermore, all the characteristic markers for $P$. hispidinervum appeared in $100 \%$ of the genotypes of this subgroup. The genetic data suggest, therefore, that the individuals from Tarauacá do indeed belong to the $P$. hispidinervum species. Possibly, this genotype is an ecotype adapted to the Tarauacá and Envira river regions with phytochemical and genetic characteristics that are different from the P. hispidinervum individuals found in the Acre river valley.

A further possibility is that the Tarauacá subgroup represents an intermediate (or possibly even a hybrid) between the $P$. hispidinervum germplasm from the Acre river basin and the $P$. aduncum germplasm from the Juruá river valley. However, none of the RAPD markers were exclusive to both $P$. aduncum and the Tarauacá group. Nevertheless, the $P$. aduncum germplasm and the Tarauaca group had 9 markers (13.6\%) in common, 5 of which with a higher frequency than $P$. hispidinervum (see Table 3), suggesting, that there may have more geneflow between the $P$. aduncum population in the Juruá valley and the Tarauacá group than between the $P$. hispidinervum and $P$. aduncum groups.

Regardless of the controversy over the level of distinction of Piper aduncum and Piper hispidinervum (species vs. variety) it is important to further examine the genetic variability that exists among high concentration safrole producing Piper populations and their distribution in South Western Amazonia as well as the similarities and dissimilarities of this germplasm to a broader range of Piper aduncum germplasm.

Although the genetic variability represented in the germplasm collection was high, the collection needs to be better structured, mainly regarding the characterization of the collection sites. The Pimenta longa germplasm was collected when little knowledge of the biology of the species was available. Isolated individuals were collected as an attempt to represent the greatest number possible of locations in which the species occurred. In addition to extensive $P$. hispidinervum collections, a number of distinct $P$. aduncum populations need to be sampled further to conclusively determine its genetic relationship with $P$. hispidinervum. Each population and collection site needs to be characterized in terms of occurrence and distribution, soil, climate, 
vegetation structure, etc. to assess each population's association with particular disturbance regimes.

Further research priorities are the studies on the floral biology and on pollination ecology of the species. Particularly, the mechanisms leading to self-pollination or the procedures needed to control cross-pollination are still unknown. It is also very important to determine whether $P$. hispidinervum and $P$. aduncum can cross to create potential hybrids and under what circumstances this may occur. In this ecological context, studies of site preferences and colonization behavior of the two species in disturbed areas are also relevant.

In future genetic studies the definition of descriptors and their assessment should be a priority for Pimenta longa germplasm collection work since Pimenta longa is a natural resource of great economic importance for the state of Acre, the Amazon region, and even for the world. However, $P$. hispidinervum, is still little studied and greater knowledge on its biology is needed, especially for genetic resource conservation purposes. The species has demonstrated potential for breeding varieties with high commercial value and needs to be explored in more detail to conclusively inform germplasm selection, propagation, and processing programs.

\section{Acknowledgments}

The authors thank CNPq for the scholarship awarded to the first author. They also thank the DFID for financial support and Embrapa Acre for technical and financial support. The second author conducted research on Piper spp. from 1995-1997 while at Florida International University and thanks the Botany in Action Program of the Garden Club of Allegheny County for financial support.

\section{References}

Almeida MC (1999) Banco de sementes e simulação de clareiras na germinação de Pimenta Longa (Piper hispidinervum C.DC.). Dissertação M.Sc, UFAC, Rio Branco, AC.

Barrett B (1994) Medicinal plants of Nicaragua's Atlantic Coast. Economic Botany 48(1):8-20.

Bhat KV, Babrekar PP and Lakhanpaul S (1999) Study of genetic diversity in indian and exotic sesame (Sesamum indicum L.) germplasm using random amplified polymorphic DNA (RAPD) markers. Euphytica 110:21-33.

Coelho ASG (2001) BOOD - avaliação de dendrogramas baseados em estimativas de distâncias/similaridades genéticas através do procedimento de bootstraps. v. 3.0. Departamento de Biologia Geral, Instituto de Ciências Biológicas, Universidade Federal de Goiás. Goiânia, GO.

Diaz PP and Gottlieb O (1979) Planta Medica 35:190.

Ehringhaus C (1997) Piper spp. (Piperaceae) Use in an indigenous Kaxinawá community in Acre, Brazil: Ethnobotany, ecology, phytochemistry and biological activity. Master's Thesis, Florida International University, Gainesville.

Ferreira ME and Grattapaglia D (1996) Introdução ao uso de marcadores moleculares em análise genética. 2nd edition. CENARGEN/Embrapa, Brasília, 220 pp.

Hegnauer $r$ (1990) Chemotaxonomie der Pflanzen. v. 9. Birkhäuser Verlag, Stuttgart.

Jain SK (1976) The evolution of inbreeding in plants. Annu Rev Ecol Syst 7:469-495.

Jensen S, Hansen J and Boll PM (1993) Lignans and neolignans from Piperaceae (Review). Phytochemistry 33(3):523-530.

Joly LG (1981) Feeding and trapping fish with Piper auritum. Econ Bot 35(4):383-390.

Linhart YB and Grant MC (1996) Evolutionary significance of local genetic differentiation in plants. Annu Rev Ecol Syst 27:237-277.

Loveless MD and Hamrick JL (1984) Ecological determinants of genetic structure in plant populations. Annu Rev Ecol Syst 15:65-95.

Maia JGS, Silva MI and Luz AIR (1987) Espécies de Piper da Amazônia ricas em safrol. Química Nova 10:200-204.

Margale E, Herve Y, Hu J and Quiros CF (1995) Determination of genetic variability by RAPD markers in cauliflower, cabbage and kale local cultivars from France. Genetic Resources and Crop Evolution 42:281-289.

Mekuria GT, Collins GG and Sedgley M (1999). Genetic variability between different accessions of some common commercial olive cultivars. Journal of Horticultural Science and Biotechnology 74:309-314.

Pimentel FA, Pereira JBM and Oliveira MN de (1998) Zoneamento e caracterização de habitats naturais de pimenta longa (Piper hispidinervum) no Acre. Rio Branco: Embrapa CPAF/AC. Boletim de Pesquisa 20, 17 pp.

Rodriguez JM, Berke T, Engle L and Nienhuis J (1999) Variation among and within Capsicum species revealed by RAPD markers. Theor Appl Genet 99:147-156.

Schultes RE and Raffauf (1990) The healing forest. Timber Press, Portland, Oregon.

Schultes RE and S. von Reis (Ed.) Ethnobotany: evolution of a discipline. Timber Press, Portland, Oregon.

Silva ACPR da and Oliveira MN de (2000) Caracterização botânica e química de três espécies do gênero Piper no Acre. Rio Branco: Embrapa Acre. Boletim de Pesquisa 23, 13 pp.

Silva MHL (1993) Tecnologia de cultivo e produção racional de pimenta longa (Piper hispidinervum C.DC). Dissertação M.Sc., UFRRJ, Seropédica, RJ.

Virk PS, Newbury HJ, Jackson MT and Ford Lloyd BV (1995) The identification of duplicate accessions within a rice germplasm collection using RAPD analysis. Theor Appl Genetics 90:1049-1055.

Williams JGK, Kubelik AR, Livak KJ, Rafalski JA and Tingey SV (1990) DNA polymorphisms amplified by arbitrary primers are useful as genetic markers. Nucleic Acids Research 18:6531-6535.

Yuncker TG (1972) The Piperaceae of Brazil. Hoehnea 2:19-366.

Editor: Márcio de Castro Silva Filho 